\title{
NILAI DIDAKTIS DALAM DONGENG ANAK JEPANG (ANALISIS DONGENG TSURU NO ONGAESHI)
}

\author{
Linda Unsriana \\ Japanese Department, BINUS UNIVERSITY \\ Kampus Kijang, Jl. Kemanggisan Ilir III No. 45, Kemanggisan/Palmerah \\ Jakarta Barat 11480, linda_unsriana@ hotmail.com
}

\begin{abstract}
The article has purpose to see the didactic value in fairy tale. The didactic value can be given to children through the character in the fairy tale by identifying the character act or behaviour. Data library shows that fairy tale can be used as one of tools for value and moral education. The data were used to support the research that fairy tale also can be used for on dan ongaeshi value. In the end, it can be concluded that fairy tale was effective tools to give value education to the children because it did not forced the children to accpet it.
\end{abstract}

Keywords: didactic value, fairy tale, Japanese children

\begin{abstract}
ABSTRAK
Artikel ini bertujuan untuk melihat nilai didaktis yang terkandung dalam dongeng. Nilai didaktis ini dapat disampaikan kepada anak melalui tokoh yang ada di dalam dongeng dengan cara mengidentifikasi perbuatan atau lakuan tokohnya. Data pustaka menunjukan bahwa dongeng dapat dipakai sebagai salah satu sarana untuk pendidikan nilai dan moral. Data ini dipakai untuk memperkuat penelitian bahwa dongeng juga dapat dipakai untuk pendidikan nilai on dan ongaeshi. Pada bagian akhir disimpulkan bahwa dongeng adalah sarana yang efektif untuk memberikan pendidikan nilai pada anak karena cara penyampaiannya yang tidak memaksa anak-anak untuk menerimanya.
\end{abstract}

Kata kunci: nilai didaktis, dongeng, anak Jepang 


\section{PENDAHULUAN}

Cerita rakyat atau dongeng dapat menumbuhkan daya imajinasi dan daya kreatif anak. Bercerita akan memberi peluang bagi anak-anak untuk ikut merasakan kesedihan, kegembiraan, dan ketegangan, dan sebagainya. Biasanya pada saat bercerita, penutur menyelipkan pesan atau ajaran. Dongeng bukanlah sekedar kata-kata, melainkan pelembagaan nilai budaya sekaligus pembungkus ajaran moral. Dongeng dapat membantu memahami perilaku masyarakat, bahkan sering kali dongeng menjadi cerminan perilaku masyarakat pendukungnya.

Dongeng dapat memberikan sesuatu yang bermanfaat. Kelebihan yang dimiliki dongeng, antara lain sebagai sarana pendidikan anak, sarana untuk mempererat hubungan orang tua dan anak, meningkatkan daya imajinasi anak, menumbuhkan daya kreativitas dan berfikir anak, serta dapat menimbulkan minat baca anak. Dari berbagai kajian, banyak diyakini bahwa dongeng mempunyai nilai lebih dari sekedar bacaan penghibur saja karena juga bermanfaat bagi perkembangan seorang anak. Nilai yang ada di dalamnya meliputi perkembangan holistik, emosional, kognitif, moral, bahasa, dan sosial (Burke dalam Bunanta, 1997:55).

Manfaat dongeng juga dikemukakan oleh Bruno Bettelheim (1976) dalam bukunya yang berjudul "The Uses of Enchantment, The Meaning And Importance of Fairy Tales", yang mengatakan:

"The Children needs a moral Education which subtly, and by implication only, conveys to him the advantages of moral behavior, not through abstract ethical concepts but through that which seems tangibly right and therefore meaningful to him. The child finds this kind of meaning through fairy tales".

Dalam tulisan ini akan difokuskan pada nilai on dan nilai balas budi (ongaeshi) dalam dongeng anak-anak Jepang yang berusaha disampaikan melalui sarana dongeng. Kata ongaeshi berasal dari kata on dan kata kaesu yang berarti mengembalikan. Konsep on mengacu pada berbagai kewajiban, yaitu kewajiban pada diri sendiri, kepada satu sama lain, kepada klan atau negara, dan kepada dunia. Kewajiban ini secara otomatis telah "dibebankan" kepada orang Jepang sejak kecil atau yang diberikan selama masa hidup mereka.

Dalam kehidupan sehari-hari, orang Jepang memperlakukan on sebagai moral umum atau konsep etika. Dengan demikian, on dianggap sebagai nilai mengenai "benar" dan "salah" yang dianut oleh bangsa Jepang. Setiap individu ditekankan untuk selalu memperhatikan hal yang berhubungan dengan utang dan rasa terima kasih. Pelanggaran terhadap norma yang berhubungan dengan on mengandung sanksi sosial yang berat. Orang Jepang yang tidak mengenal etika ini disebut orang yang tidak kenal on atau onshirazu. Sebutan itu merupakan sebutan penghinaan dalam kehidupan orang Jepang (Benedict, 1979:121-148).

\section{PEMBAHASAN}

\section{Dongeng dan Mukashi-Banashi}

Yanagita Kunio dalam bukunya yang berjudul "Mukashi Banashi Oboegaki" (Catatan Mukashi-Banashi) menjelaskan tiga ciri umum mukashi banashi. Pertama, pada bagian permulaan, dimulai dengan kata seperti mukashi atau mukashi mukashi. Dapat juga tergantung dari daerah tempat cerita berasal, seperti tonto mukashi, zatto mukashi, mukashi ga atta kedo, mukashi ga atta souna. Jika mendengar kata-kata seperti disebutkaan, kita langsung dapat mengetahui bahwa itu adalah mukashi 
banashi. Kedua, pada bagian akhir cerita ditutup dengan kalimat yang membahagiakan, seperti medetashi-medetashi, magoko shigeta, iccho hanjo saketa. Kalimat itu biasanya memperlihatkan keberhasilan tokoh utamanya. Ketiga, bagian yang penting pasti ditekankan dengan kata-kata souna, gena, tosa, dan lain-lain. Kata-kata seperti itu dalam konjaku monogatari berbunyi totan katari tsutaetarutoya (cerita disampaikan) atau hontoka douka shiranai (betul atau tidak saya tidak tahu\}, jibun wa sou kiiteiru (yang saya dengar begitu).

Penyampaian dongeng disebut mukashi fukataru. Perbedaan mukashi banashi dengan cerita lainnya adalah pada awal dan akhir cerita. Dengan kata lain, pada mukashi banashi ada ketentuan. Dalam tiap daerah atau wilayah, memang ada perbedaan dalam penyampaian awal dan akhir mukashibanashi tetapi pencerita atau pendongeng pasti menyebutkan kata mukashi atau mukashi-mukashi no sono mukashi, mukashi aggedona, tonto mukashi ga attatenggana pada awal bercerita, dan akan diakhiri dengan kata medetashi, donbekkara koekedo, ikigabo tosaketa, dottohare, sutton katan. Di daerah tertentu ada kebiasaan untuk melakukan doa untuk memulai cerita (Takuzo, 1988:365).

Dalam kamus "Minzoku no Jiten”, mukashi banashi diklasifikasikan menjadi tiga bagian besar, yaitu honkaku mukashi-banashi (dongeng asli), dobutsu mukashi banashi (dongeng binatang), warai mukashi banashi (dongeng jenaka). Nomura Junichi dalam bukunya yang berjudul "MukashiBanashi no Densho" mengemukakan tentang cara penyampaian mukashi-banashi, yaitu yang disampaikan atau diadakan di dalam rumah dan yang diadakan di pusat kota atau desa. Pencerita yang andal pada mulanya mendengarkan mukashi banashi berulang kali dari orang-orang tua di rumah, selanjutnya mereka bertanding di antara pemuda. Lebih lanjut dikatakan pula bahwa mukashi banashi ditransmisikan pada anak-anak. Di dalam rumah, pada malam bersalju, anak-anak bermain di tepi perapian rumah sambil mendengarkan mukashi-banashi.

Mukashi banashi juga diceritakan di pusat kota atau pusat desa, misalnya di daerah Yamagata, para pemuda saling mendengarkan dan saling bercerita serta mengadakan pertandingan bercerita pada malam sebelum diadakan matsuri (festival). Selain teman-teman sekampung, orang-orang yang melakukan perjalanan (pengelana) yang sering berkunjung ke desa kerapkali menceritakan mukashi banashi. Selain para pengelana, para pendeta, tukang obat, dan para pedagang yang sedang melakukan perjalanan untuk mengadakan transaksi turut membantu penyebaran mukashi banashi di Jepang.

\section{Fungsi Dongeng Sebagai Sarana Penanaman Nilai Moral}

Melalui dongeng, anak dapat mengembangkan emosi secara sehat. Anak-anak menghayati, merasakan, dan meresapi dongeng tidak melalui akalnya, melainkan melalui emosinya. Itulah sebabnya, mengapa dongeng tidak perlu logis. Dongeng yang baik adalah dongeng yang dapat mengembangkan kepribadian anak sebaik-baiknya sesuai dengan tuntutan masyarakat di sekitarnya (Handayu, 2001:71-75).

Berhubungan dengan perkembangan religiusitas anak, Clark merumuskan teori diantaranya diistilahkan sebagai unrefllective, yaitu anak menerima konsep keagamaan berdasarkan otoritas atau kekuatan. Pengetahuan yang masuk pada usia awal dianggap sebagai sesuatu yang menyenangkan, terutama yang dikemas dalam bentuk cerita. Oleh karena itu, konsep tentang nilai keagamaan dapat sebanyak mungkin diberikan pada usia awal dan sebaiknya disampaikan dalam bentuk cerita. Banyak orang tidak menyadari besarnya pengaruh cerita terhadap perilaku seseorang, misalnya cerita yang mengajarkan dasar kehidupan beragama dan aturan dalam berperilaku. Demikian pula dengan dongeng binatang dan legenda yang ikut mencetak nilai budaya yang akan membentuk sikap anak.

Cerita menjadi sarana efektif untuk mempengaruhi cara berpikir dan berperilaku anak-anak karena mereka senang mendengarkan atau dibacakan berulang-ulang. Perulangan itu dipadukan dengan imajinasi anak-anak menjadikan cerita sebagai salah satu cara terbaik untuk mempengaruhi 
cara berpikir mereka. Shari Lewis dalam bukunya "The One Minute Bedtime Story" menekankan pentingnya bercerita untuk perkembangan anak. Selama sepuluh tahun, para psikolog telah mengemukakan pengaruh positif orang tua membacakan cerita dan bercerita kepada anak-anaknya. Kegiatan membacakan buku cerita pada anak dapat dipakai sebagai media penyampaian pesan mengenai aturan serta norma yang berlaku di masyarakat (Handayu, 2001:75-76).

Dalam Children and Literature, Stewig (1980:9) mengemukakan bahwa sejak awal tahun 1900 para pengarang dan pendidik mulai memusatkan perhatiannya pada masalah didaktik, khususnya pada cerita anak-anak. Selanjutnya, pada tahun 1920, mereka memusatkan konsentrasinya untuk mempelajari kebutuhan anak-anak sehubungan dengan bacaannya. Menurutnya, buku untuk anak-anak dalam penyajiannya hendaknya juga memikirkan jiwa anak-anak daripada hanya sekedar menghibur. Dongeng dapat memberikan kesenangan pada anak-anak karena pada mulanya dongeng diceritakan untuk menghibur. Namun demikian, pada dongeng juga terdapat ajaran yang ingin disampaikan. Dongeng dikatakan sebagai alat pendidikan anak karena dongeng mendidik sekaligus menghibur. Hal itu karena pada umumnya sastra lama bersifat didaktis, yakni memberikan pengajaran bagi para pembacanya, hal yang bersifat didaktis moral maupun didaktis religius. Pendidikan yang disampaikan melalui dongeng tentu berbeda dengan corak bacaan lainnya karena dongeng mempunyai ciri-ciri tersendiri yang menunjukkan kekhasannya.

Dongeng (mukashi banashi) sebagai sarana pengajaran moral juga diungkapkan oleh Komatsu Kazuhiko, berdasarkan tulisannya yang terangkum dalam buku yang berjudul Mukashi Banashi Kenkyu no Kadai, ia menuliskan bahwa selain dipergunakan sebagai sarana pendidikan moral, mukashi banashi juga dipakai untuk menyampaikan ajaran agama. Agama Budha memberikan ajaran atau kotbahnya antara lain melalui mukashi banashi. Penyampaian ajaran agama dengan sarana mukashi banashi juga dilakukan agama Kristen di Eropa dalam abad pertengahan (Kazuhiko, 1985:36).

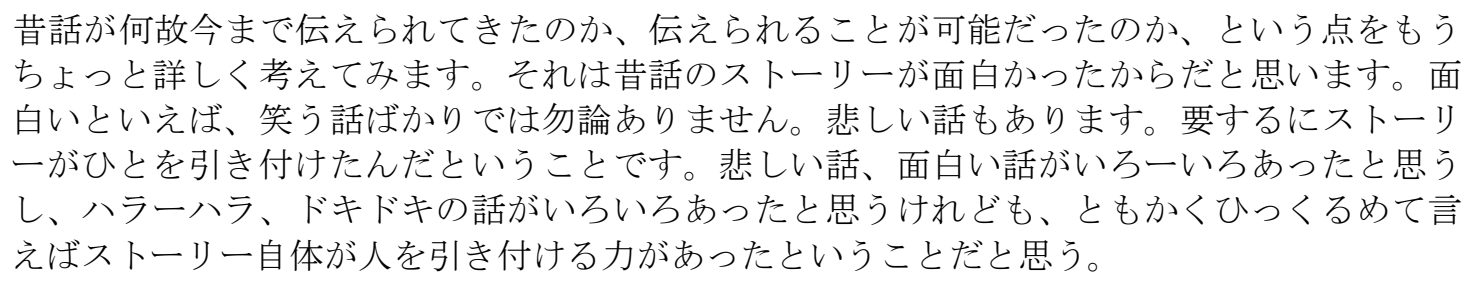

"Mukashi banashi ga naze ima made tsutaeraretekitanoga kanodattanoka, toiu ten o mouchottokuwashiiu kangaete mimasu. Sore wa mukashi-banashi no sutori ga omoshirokatta karadato omoimasu. Omoshiroi to ieba, warau banashi bakari dewa mochiron arimasen. Kanashii hanashi mo arimasu. Yousuruni sutori ga hito wo hikitsuketandatoiu koto desu. Kanashii hanashi, omoshiroi hanashi ga iro-iro atta to omoushi, hara-hara, doki-doki no hanashi ga iro-iro atta to omoukeredomo, tomokakuhikkurumete ieba sutori jitai ga hito wo hikitsukeru chikara ga atta to iu koto datou omou".

\section{Terjemahannya:}

"Mengapa mukashi-banashi hingga saat ini masih terus disampaikan. Saya pikir karena mukashi-banashi mempunyai cerita yang menarik. Apa yang dikatakan dengan menarik itu bukan hanya cerita cerita lucu saja. Ada juga cerita-cerita yang sedih. Dengan kata lain, ceritanya menarik perhatian orang. Cerita-cerita yang sedih, cerita yang menarik, yang menakutkan, mendebarkan, ada dalam mukashi-banashi. Dapat dikatakan bahwa cerita mukashi-banashi itu mempunyai kemampuan untuk menarik perhatian orang" (Ozawa, 2000:28).

Selain menarik minat anak-anak, mukashi banashi juga mengandung ajaran moral. 
昔話というのは、わりと道徳教育的な、教訓的な話であるという受け取り方が多いとおもう んです。

"Mukashi-banashi to iu nowa, warito kyoukunteki na hanashi de aru toiu uketori kata ga ooito omoundesu”.

\section{Terjemahannya:}

"Di dalam mukashi banashi lebih banyak cerita yang mengandung ajaran moral dan etika".

明治以来、あるいはもうちょっと前ぐらいに勧善懲悪の物語というのが教育的にいいという わけで、教科書に取り入れられたり、たびたび絵本になったりしてきたから有名になっただ けの話だと思います。

"Meiji irai, aruiwa mou chotto mae gurai ni, kanzenchouaku no monogatari to iu noga kyouikuteki ni iitoiuwakede, kyoukasho ni toriireraretari, tabi-tabi $e$ hon ni nattarishitekitakara yuumei ni nattadake no hanashi dato omoimasu".

\section{Terjemahannya:}

"Sejak jaman Meiji, atau mungkin sebelumnya, tema kanzen choaku dianggap sebagai tema yang baik, sehingga dimasukkan dalam buku-buku pelajaran, dan sering dimasukkan dalam buku cerita bergambar, dan menjadi buku cerita yang terkenal" (Ozawa, 2000:30).

\section{Pengertian On dan Ongaeshi}

Di dalam bukunya yang berjudul Pedang Samurai dan Bunga Seruni, Ruth Benedict mengemukakan on sebagai "utang", "utang budi", "kewajiban", atau "kemurahan hati". On juga mengandung arti beban atau suatu utang, sesuatu yang harus dipikul seseorang sebaik mungkin. On juga menunjuk kepada utang psikologis maupun sosial yang dikenakan kepada seseorang atas penerimaan bantuan. Secara moral si penerima on wajib membalas bantuan atau pemberian yang telah ia terima. Seseorang yang menerima on, baik dari atasannya maupun dari siapa saja maka akan menimbulkan perasaan bahwa orang yang menerima tersebut statusnya lebih rendah daripada si pemberi on (Benedict, 1979:105).

Lebra bahkan menggambarkan on sebagai jaminan sosial yang dapat digunakan disaat krisis. Ketika mengalami kesulitan, onjin (orang yang memberikan on) tidak perlu bersusah payah meminta bantuan tetapi bantuan itu akan segera datang dari orang-orang yang pernah menerima on darinya, ketika mereka tahu si pemberi on sedang dalam kesulitan (Lebra, 1976:96). Berbeda dengan pendapat yang dikemukakan Lebra, Umesao Tadao berpendapat bahwa on bukanlah tiket dua arah yang dapat digunakan jika sewaktu-waktu memerlukannya. Akan tetapi, menurutnya on adalah tiket satu arah (one way ticket) yang jika sudah diberikan maka tidak mengharap balasan, seperti dalam kutipan berikut.

恩とは片道切符であって、復券なし、ということをぐるしたものかもしれない。

"On to wa kata michi kippu deatte, fukken nashi, toiu koto o gurushita mono no kamoshirenai”.

Selanjutnya, dalam buku yang berjudul Nihonjin no Kokoro (Hati Orang Jepang), Tadao mengemukakan:

恩は基本的には、動物報恩話のように無償の行為なのである。自発的善意にもとづいて施し、 かつを返しを期待しないものである。寓話ならいざしらず、人間が鳥獣に恩を施したからと いって、だれも実際に、そのお返しを期待する者はいまい。恩とは、もともとそんなものな のだ。恩が与えられるから奉公する。だから恩は当初は契約関係で発生した。つまり有限な 
ものである。それが次第に「海よりも梁く、山よりも高く」と、無限へ拡大していったから 手に負えなかった。

"On wa kihon teki ni wa,doubutsu houonbanashi no youni mushou no koi nanodearu. Jihatsu teki zeni ni motozuite hodokoshi, katsu okaeshi kitaishinai mono de aru. Guwa nara izashirazu, ningen ga torikedamono ni on o hodokoshitakara to itte, daremo jissai ni, sono okaeshi o kitaisuru mono ha imai. On to wa, moto-moto sonna mono nanoda. On ga ataerareru kara houkou suru. Dakara on wa tousho wa keiyaku kankei de hasseishita. Tsumari yuugen na mono de aru. Sore ga shidai ni "Umi yorimo fukaku, yama yorimo takaku" to, mugen e kakudai shite ittakara te ni oenakatta".

Kutipan tersebut pada intinya menyatakan bahwa on pada dasarnya adalah suatu perbuatan yang tidak mengharapkan balasan, seperti yang tampak pada cerita hoon binatang. Suatu tindakan yang secara spontan memberikan kebaikan dan tidak mengharapkan suatu pengembalian. Ada pepatah yang merupakan ajakan "Orang memberikan on kepada makhluk lain, sebenarnya tidak mengharapkan okaeshi (pengembalian)." Pada mulanya, on mempunyai arti seperti itu. Akan tetapi selanjutnya, orang yang telah menerima on akan memberikan jasanya. Oleh karena itulah, on membuat hubungan yang bersifat kontrak. Selanjutnya, dikatakan bahwa on lebih dalam dari lautan (umi yorimo fukaku), lebih tinggi dari gunung (yama yori mo takaku), menggambarkan betapa beratnya beban on yang harus ditanggung penerimanya (Tadao, 1982:190).

Selanjutnya, Tadao juga mengemukakan bahwa:

恩とよく並列して出てくる義理は、金の貸借勘定であった。だから「あそこに義理がある、 なんぼや」と返せば、義理はなくなってすっきりする。ところが恩は海よりも深く、山より も高いとあっては、どうにも返しようがない。決算することのできないものに、一生しばら れる。本来、自由な存在であるべき人間にとっては恩は大きな問題だ。恩がヨコの関係であ った昔は、それなりに精算はできたが、上下のタテの関係になってから無限となり、精算は 不能となった。まるでキモノのように着たり、着せられたりして、裸になることができなく なった。そういえば、恩は着る、着せられるといい、義理はからむという。

"On to yoku heiretsu shite dete kuru giri wa, kane no taishaku kanjou de atta. Dakara "Asoko ni giri ga aru, nanboya" to kaeseba, giri wa nakunatte sukkiri suru. Tokoro ga on wa umi yorimo fukaku, yama yorimo takai to atte wa, dounimo kaeshiyou ga nai. Kessan suru koto no dekinai mono ni isshou shibarareru. Honrai, jiyu na sonzai de aru beki ningen ni totte wa, on wa ookina mondaida. On ga yoko no kankei de atta mukashi wa, sorenari ni seisan wa dekita ga, jouge no tate no kankei ni natte kara mugen to nari, seisan wa funou to natta. Marude komono no youni kitari, kiseraretari shite, Hadaka ni naru koto ga dekinakunatta. Soieba, on wa kiru, kiserareru to iu, giri wa karamu to iu”.

\section{On dan Ongaeshi sebagai Moralitas Orang Jepang}

Pertukaran on dapat dilihat dari pertukaran sosial yang ada dalam masyarakat. Dalam suatu hubungan yang dilandasi on, kedudukan sebagai penerima on memaksa seseorang untuk mengembalikan utangnya. Perasaan harus mengembalikan apa yang telah diterima berasal dari rasa terima kasih yang kuat yang berhubungan dengan on yang telah ditanamkan sebagai dasar dari karakter moral bangsa Jepang. Rasa terima kasih dapat diekspresikan secara verbal dan dapat juga melalui tindakan nyata. Rasa terima kasih biasanya diekspresikan melalui kata-kata seperti arigatai (terimakasih) atau dalam bahasa percakapan menjadi arigato. Sering juga rasa terima kasih diekspresikan dengan kata sumanai yang dapat diartikan maaf. Mungkin penerima merasakan rasa terima kasih dan rasa maaf sekaligus. Hal itu didasari oleh suatu kesadaran dari penerima on terhadap pengorbanan pemberi on dan juga kesadaran bahwa ia tidak mampu membayar utang itu sepenuhnya. 
Dalam mengekspresikan rasa terima kasihnya, orang Jepang lebih memilih kata "minta maaf" daripada kata "terima kasih". Konsep on adalah dasar dari moralitas bangsa Jepang yang meliputi rasa terimakasih yang dalam dan perasaan bersalah. Akan tetapi, on tidak selalu mendatangkan reaksi positif dari moral. On juga seringkali juga dipandang sebagai suatu beban berat yang harus segera dihilangkan. Konsep on Jepang berasal dari kekuatan moral dari budaya resiprositas. Meskipun on dapat merujuk pada pertukaran pemberian secara spesifik, implikasi moralnya berada pada hubungan antara suatu perbuatan baik dan suatu kewajiban (generelized benevolence and generelized obligation). Perbuatan baik adalah kewajiban moral yang ditekankan dalam budaya Jepang di bawah nama shinsetsu (kebaikan), nasake (kasihan), jihi (kemurahan hati), awaremi (simpati), dan omoiyari (empati).

Orang Jepang telah diajarkan tentang rasa kebajikan yang tidak hanya tertuju pada manusia tetapi juga pada binatang, termasuk juga serangga. Ajaran Budha juga memberikan kontribusi dalam mengajarkan kebajikan yang tidak meminta imbalan. Suatu perbuatan baik tidak dibatasi pada peristiwa tertentu saja, tidak juga dihitung secara ekonomi atau harus dikembalikan. Perbuatan baik lebih menekankan pada perilaku si pemberi daripada nilai benda yang diberikan atau tindakan tertentu. Semua itu berarti bahaya ego sebagai penerima on harus menyadari dan tidak melupakan perilaku atau tindakan serta perbuatan baik dari onjin-nya.

\section{Analisa On dan Ongaeshi dalam Dongeng Tsuru no Ongaeshi}

\section{Penokohan dalam Tsuru no Ongaeshi}

Tokoh/pelaku dalam dongeng ini ada tiga orang. Tokoh utama dalam cerita ini adalah seorang kakek yang digambarkan sebagai orang yang miskin tetapi sangat baik hatinya. Pekerjaan kakek tua itu adalah menjual kayu bakar ke kota. Kakek digambarkan sebagai orang yang mau bekerja keras. Di musim dingin, dimana salju turun terus menerus, kakek tetap berusaha sekuat tenaga untuk menjual kayu bakarnya.

Tokoh sentral lainnya dalam dongeng Tsuru no Ongaeshi ini adalah seekor burung bangau. Karena ingin membalas budi kepada kakek yang telah menolongnya, ia mengubah dirinya menjadi seorang gadis. Tokoh gadis jelmaan burung bangau ini digambarkan sebagai seorang wanita muda berusia sekitar 17 atau 18 tahunan yang sangat cantik. Ia juga digambarkan sebagai gadis yang rajin bekerja dan melakukan setiap pekerjaan dengan hasil yang memuaskan. Gadis jelmaan burung bangau juga digambarkan sebagai orang yang tahu membalas budi. Balas budi yang diberikannya kepada orang yang telah menolongnya, yaitu dengan memberikan bantuan untuk menyelesaikan pekerjaan rumah tangga. Selain itu, ia juga memberikan bantuan yang bersifat ekonomi dengan cara menenun kain yang indah. Kain itu laku dijual dengan harga yang tinggi sehingga ekonomi keluarga kakek dan nenek mulai membaik.

Tokoh lainnya dalam dongeng ini adalah tokoh nenek. Tokoh nenek yang digambarkan sebagai orang yang baik hati. Tokoh nenek ini juga digambarkan sebagai orang, yang karena rasa ingin tahunya yang besar, akhirnya melanggar janji yang telah disepakati. Konsekuensi dari pelanggaran janji, gadis jelmaan burung bangau itu pergi meninggalkan kakek dan nenek. Gadis itu kembali ke bentuk asalnya menjadi burung bangau.

\section{Alur Cerita Tsuru no Ongaeshi}

Di dalam sebuah cerita rekaan, berbagai peristiwa disajikan dengan urutan tertentu. Urutan peristiwa yang membangun tulang punggung cerita disebut alur (Sudjiman, 1992:29). Dongeng berjudul Tsuru no Ongaeshi, diawali dengan satu peristiwa, yaitu peristiwa dimana kakek penjual 
kayu bakar menolong seekor burung bangau yang terjerat. Dari peristiwa itu lalu muncul peristiwa lainnya, yaitu datangnya seorang gadis muda ke rumah kakek penjual kayu bakar untuk menolong kakek dan nenek. Kakek dan nenek tidak mengetahui siapa sebenarnya gadis muda itu.

Gadis yang tidak diketahui asal-usulnya itu setiap hari membantu pekerjaan kakek dan nenek. Ia juga membantu kakek dan nenek mendapatkan uang dengan cara menenun kain yang sangat indah dan dijual dengan harga yang tinggi. Begitulah cara burung bangau membalas budi. Klimaks dari dongeng Tsuru no Ongaeshi ini, yaitu dengan peristiwa perginya gadis jelmaan burung bangau karena janji yang telah dibuatnya dengan kakek dan nenek telah dilanggar oleh nenek.

\section{Tema dan Amanat Tsuru no Ongaeshi}

Tema dongeng yang berjudul Tsuru no Ongaeshi ini sebenarnya telah dinyatakan secara eksplisit, terlihat dari judulnya. Tsuru no Ongaeshi yang berarti balas budi burung bangau. Di dalamnya dengan jelas dideskripsikan bagaimana usaha burung bangau untuk membalas budi orang yang telah menolongnya. Mula-mula ia mengubah wujudnya dalam wujud seorang gadis muda agar ia dapat membantu pekerjaan kakek dan nenek. Akan tetapi, bantuan yang ia berikan dirasakan belum cukup untuk membalas budi. Gadis muda itu lalu menenun kain yang sangat indah siang dan malam tanpa kenal lelah. Kain yaang indah itu ditenunnya dari bulu-bulunya sendiri.

Amanat dalam dongeng ini adalah tidak melupakan on seseorang yang telah menolong kita. Bagaimanapun juga on seseorang harus dibalas. Amanat lainnya dalam dongeng ini adalah bahwa kita tidak boleh melanggar janji. Hal ini digambarkan dengan tokoh nenek yang telah melanggar janji pada burung bangau. Kakek dan nenek sebelumnya telah berjanji untuk tidak mengintip gadis muda itu ketika sedang menenun. Akan tetapi, karena keingintahuan yang besar nenek mengabaikan janjinya untuk tidak mengintip ketika gadis muda itu sedang menenun. Konsekuensi dari pelanggaran janji tersebut, yaitu perginya burung bangau meninggalkan kakek dan nenek.

\section{On dan Ongaeshi dalam Dongeng Tsuru no Ongaeshi}

Dalam cerita ini, perbuatan atau tindakan yang menggambarkan on dimulai ketika kakek menolong burung bangau yang terperangkap dan terikat kakinya. Dengan perbuatan menolong tersebut, kakek telah menanamkan on kepada burung bangau. Dengan terjadinya hubungan antara si penolong dan yang ditolong atau pemberi dan penerima on maka penerima on akan berusaha mengembalikan on yang telah diterimanya.

Ongaeshi dalam cerita ini dapat dilihat dari percakapan dan tindakan yang dilakukan penerima on (burung bangau) dan pemberi on atau onjin (kakek penjual kayu bakar). Burung bangau yang telah ditolong jiwanya oleh kakek, berusaha menemukan penolongnya meskipun pada saat itu cuaca sangat dingin dan hujan salju turun dengan lebatnya. Dengan mengubah bentuk aslinya menjadi seorang perempuan muda, ia datang ke rumah kakek untuk mulai membalas budinya, dengan cara membantu apa yang dapat dilakukannya. Menyiapkan makan malam, membereskan rumah, memijat kakek dan nenek, meskipun ia sendiri sudah lelah. Kutipan berikut menjelaskan bagaimana burung bangau mengembalikan on-nya kepada kakek:

おばあさん、晚のしたくを、てつだわせてくださいませ。そういました。いやいや、うちは、 貧乏だからな、手伝ってもらうほどの仕事もない。おまえは、そこに、あたっていなさい

よ。」おばあさんが言いましたが、娘は聞きません。そして、「どうかわたしにさせてくだ さい。」たのむように、そういうものですから、すめにさせてみますと、ごはんをたくのも じょうずなら、おかずをつくるのもじょうず、そのうえ、しんせつで、ていねいで米一つぶ もこぼしません。おじいさにやおばあさんのお給仕をして、それから、じぶんもたべて、そ のあとをきれいにかたずけて、ちょっとおちついたかとうおもうと、すぐ、おじいさんおう しろへまわっていいました。「おじいさん、おじいさん、昼のおつかれで、肩やお腰がこっ 
ていましょう。へたではございますが、あんまをさせてくださいませ。」「いやいや、おま えさんこそ、おつかれだろう。今夜は大雪で、ずいぶん寒い。ずっとこっちへきて、ようく 火にあたりなさい。」おじいさんがいってみききません。それで、あんまをしてもらいま すと、とてもじょうずで、うとうとするほどよい気持ちです。おじいさんがすむと、こんど は、おばあさんのあんまもするというありさまです。

"Obaasan, ban no shitaku o,testudawasetekudasaimase", so iimashita. Iya..iya, uchi wa, bimbou dakarana, tetsudattemorau hodo no shigotomonai. Omae wa, soko ni, tatteinasaiyo. "Obaasan ga iimashita ga, musume ha kikimasen. Soshite, "Douka watashi ni sasetekudasai. "Tanomuyouni, souiumonodesukara, musume ni sasetemimasuto, gohan o taku no mo jouzudesukara, okazu o tsukuru no mo jouzu, sonoue, shinsetsu de, teineide kome hitotsubu mo koboshimasen. Ojiisan ya obaasan no okyuuji o shite, sorekara, jibun mo tabete, sono ato o kirei ni katazukete, chotto ochitsuitekato omou to, sugu, ojiisan no ushiro e mawatteiimashita."Ojiisan, ojiisan, hiru no otsukarede, kata ya okoshi ga kotteimashou. Heta de wa gozaimasu ga, anma o sasete kudasaimase. "Iya.iya, omaesan koso, otsukaredarou. Konya wa ooyuki de, zuibun samui. Zutto kochi e kite, youku hi ni atarinasai. Ojiisan ga ittemo kikimasen. Sorede, anma o shitemoraimasuto, kondo wa, obaasan no anma mo suru to iu arisama desu".

\section{Terjemahannya:}

"Nenek, biarkan saya menolong nenek menyiapkan makan malam", perempuan muda itu berkata. Nenek menjawab,"Kami sangat miskin, hingga tidak ada pekerjaan yang membutuhkan bantuan. Kamu berdiri saja di sana." Meskipun nenek sudah berkata demikian, sepertinya perempuan muda itu tidak mendengarkan ucapan nenek. "Tolong ijinkan saya membantu nenek," katanya. Karena ia betul-betul memohon, akhirnya kakek dan nenek memperbolehkannya membantu. Ternyata pekerjaannya sangat memuaskan. Ia pandai memasak nasi, tidak menumpahkan beras sebutir pun, ia juga pandai memasak lauk pauk, selain itu ia juga ramah dan sopan. Setelah menyelesaikan semua perintah kakek dan nenek, barulah ia makan, lalu merapikan semuanya. Setelah pekerjaannya selesai, ia tidak segera beristirahat, melainkan berjalan mendekati kakek, lalu menawarkan apakah kakek ingin dipijat. "Kakek kan sudah letih bekerja seharian, pundak dan pinggang kakek pasti pegal. Biarpun saya tidak pandai memijat, mari saya pijat kakek", kata perempuan itu. "Tidak usah, kamu sendiri sudah letih, perjalanan kamu pasti jauh, ditengah hujan salju yang dingin lagi. Sudahlah, pergilah mengangatkan badanmu di perapian". Ia tidak mendengarkan perintah kakek, lalu mulai memijat. Setelah memijat kakek, ia juga memijat nenek".

Tidak hanya dalam tindakannya yang selalu berusaha membantu kakek dan nenek dalam menyelesaikan pekerjaanya saja tetapi ia juga berjanji untuk selalu setia kepada kakek dan nenek, seperti tampak pada kutipan berikut:

いたらない者ではありますが、いっしょうけんめい孝行いたします。

"Itaranai mono de wa arimasu ga, issyoukenmei ni koukouitashimasu”.

\section{Terjemahannya:}

"Walaupun saya memiliki banyak kekurangan, saya berjanji akan setia pada keluarga ini".

Merasa bantuan yang telah diberikannya pada kakek dan nenek, dengan cara menolong pekerjaan mereka belum cukup untuk mengembalikan on yang telah diterimanya dari kakek, si burung bangau yang menjelma menjadi perempuan muda itu terus berupaya membayar on-nya dengan cara menenun kain yang indah yang akan dijual ke pasar. Uang hasil penjualan kain itu diharapkan dapat membantu perekonomian kakek dan nenek. 
その日は、むすめは、ごはんもたべないで、いっしょうけんめい、はたを織りつづけまし た。晚になると、その織場からでてきましたが、あくる日も、また、びょうぶのなかで、キ イトン、バタバタ、キイトン、バタバタと、一生懸命にやりました。

"Sono hi wa, musume wa, gohan mo tabenaide, issyoukenmei, hata o oritsuzukemashita. Ban ni naru to, sono oriba kara detekimashita ga, akuru hi mo, mata, byoubu no naka de, issyoukenmeini yarimashita".

\section{Terjemahannya:}

Pada hari ia menenun, anak perempuan itu tidak makan, kerjanya hanya menenun terusmenerus. Baru pada malam harinya ia keluar dari ruangan. Hari berikutnya ia melakukan pekerjaan yang sama, menenun dengan sungguh-sungguh.

Kain yang ditenun oleh perempuan muda itu sangat indah sehingga dapat dijual dengan harga yang tinggi. Akan tetapi, sebenarnya kain yang ditenun itu berasal dari bulu-bulu burung bangau yang mengubah dirinya menjadi perempuan muda untuk membalas budinya kepada kakek yang telah menolong menyelamatkan dirinya dari perangkap. Ungkapan terima kasih dari perempuan muda itu, tampak dalam kutipan berikut.

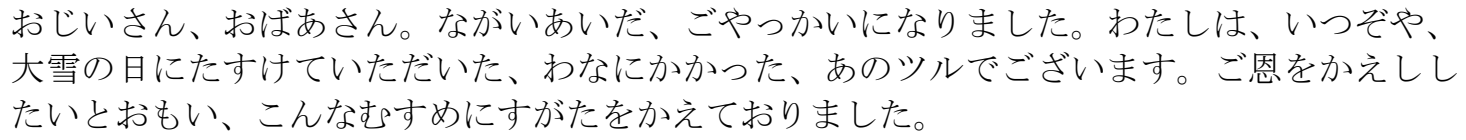

"Sono ban no koto desu. Oriageta ayanishiki o motte dete kita musume wa, ojiisan, obaasan no mae niryoute o tsuite iimashita. Ojiisan, obaasan. Nagai aida, goyakkai ni narimashita. Watashi wa, itsu zoya, ooyuki no hi ni tasukete itadaita wana ni kakatta, ano tsuru de gozaimasu. Go On o okaeshishitai to omoi, konna musume ni sugata o kaete orimashita".

\section{Terjemahannya:}

"Pada malam hari, akhirnya, anak perempuan itu membawa kain yang baru saja selesai ditenunnya. Kemudian ia berkata," Kakek dan nenek telah banyak membantu saya. Sebenarnya saya adalah burung bangau yang pernah di tolong kakek ketika saya terperangkap. Saya pikir, saya harus mengembalikan $O n$ yang telah saya terima, maka saya merubah diri saya seperti ini".

Begitulah cara burung bangau mengembalikan on (ongaeshi) kepada penolongnya. Dalam dongeng "Tsuru no no Ongaeshi", kita dapat menangkap bahwa bantuan yang diberikan kakek pada burung bangau adalah bantuan yang tulus tanpa mengharapkan imbalan. Itu adalah bentuk dari ninjo (rasa kemanusiaan) yang merupakan ungkapan dari kebaikan hati dan rasa sayang yang dimiliki seorang manusia.

Arti on sebagai bantuan yang tulus tanpa mengharapkan imbalan sesuai dengan apa yang dikatakan Umesao Tadao dalam bukunya yang berjudul "Nihon jin no Kokoro" (Hati Orang Jepang). Bahwa on timbul dengan sendirinya dari perasaan kasihan atau simpati yang merupakan salah satu dari sisi kebaikan. Setelah memberi pertolongan, timbul perasaan senang dan puas. Perasaan senang karena telah menolong juga dapat dikatakan sebagai imbalan yang didapat seseorang (Tadao, 1982:191). Dalam dongeng ini perasaan senang setelah menolong, juga timbul dalam diri kakek penjual kayu bakar, seperti tampak dalam kutipan berikut.

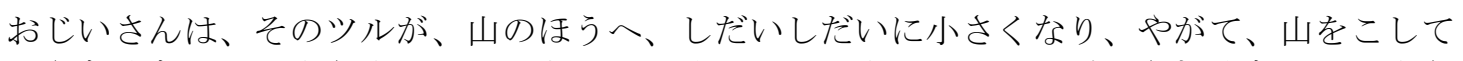


と、おじいさんは、ひとりごとをいいました。「よいことをしてやった。どうやら、きょう は、運のよい日らしい。」おじいさんは、よい気持ちになって、それから、また、まきをか ついで、町へでかけていきました。

"Ojiisan wa, sono tsuru ga, yama no hou e shidai shidai ni chiisaku nari, yagate, yama o koshite mienakunatte shimau made, sore o, miokutte orimashita. Tsuru ga mienakunatte shimau to, ojiisan wa, hitori goto o iimashita. "Yoi koto o shite yatta. Douyara, kyou wa, un no yoi hi rashii." Ojiisan wa, yoi kimochi ni natte, sorekara, mata, maki o katsuide, machi e dekakete ikimashita".

\section{Terjemahannya:}

"Setelah burung bangau tidak kelihatan lagi dari pandangan kakek, kakek lalu berkata seorang diri, "Saya telah melakukan sesuatu hal yang baik. Kelihatannya, hari ini adalah hari keberuntunganku". Perasaan kakek menjadi senang. Lalu ia memikul kembali kayu bakarnya dan berangkat menuju kota".

Salah satu pesan yang ingin disampaikan pada anak-anak yang mendengar atau membaca dongeng ini adalah menolong tanpa mengharapkan pamrih. Menolong orang tanpa mengharapkan imbalan adalah moral penting yang ingin di sampaikan, meskipun pada akhirnya perbuatannya mendapatkan balasan (ongaeshi). Akan tetapi, bukanlah harapan untuk mendapatkan balasan atas bantuan yang telah diberikan yang dikejar. Balasan yang didapat adalah hasil dari perbuatan kita, bukan suatu keharusan untuk mendapatkannya.

Dalam dongeng "Tsuru no Ongaeshi", penulis melihat ada beberapa pesan atau amanat yang ingin disampaikan oleh pembuat ceritanya. Pesan utama yang ingin disampaikan adalah balas budi kepada orang yang telah menolong atau menyelamatkan kita. Pesan lainnya adalah bahwa kita tidak boleh melanggar janji yang telah kita buat. Dalam dongeng ini, pelanggaran terhadap janji yang telah disepakati dapat dilihat dari kutipan berikut.

私はこれから、はたを織りますから、織っているうちは、どんなことがあっても、なかをの ぞいてはいけませんよ。どうかなかをみないようにしてください。」おじいさん、おばあさ んは、「よいともよいとも、どんなことがあっても、のぞきはしないから、安心して織りな さい。

"Watashi wa korekara, hata o orimasu kara, otteiru uchi wa, donna koto ga attemo, naka o nozoite wa ikemasenyo. Dooka naka o minaiyouni shitekudasai". "Yoitomo,yoitomo, donna kotoga attemo, nozoki wa shinaikara, anshinsite orinasai”.

\section{Terjemahannya:}

"Karena mulai sekarang saya akan menenun kain, selama saya sedang menenun, biar ada kejadian apapun juga, tolong jangan mengintip ke dalam", kata perempuan muda itu. "Baiklah, baiklah, walaupun apa yang akan terjadi, kami tidak akan mengintip ke dalam, menenunlah dengan tenang," jawab kakek".

Meskipun telah berjanji, pada akhirnya nenek tidak menepati janjinya. Ia mengintip anak perempuannya yang sedang menenun di dalam kamar. Akan tetapi, nenek tidak menemukan anak perempuannya. Ia hanya melihat seekor burung bangau yang sedang menenun. Hasil dari perbuatan nenek yang melanggar janji membawa akibat perginya anak perempuan mereka, yaitu jelmaan burung bangau. Pembuat cerita ini ingin memberi ajaran moral bahwa berbuat baik akan menerima hasil yang baik dan berbuat tidak terpuji juga akan mendapat balasan setimpal. 


\section{PENUTUP}

Dari uraian yang telah dikemukakan, dapat disimpulkan bahwa nilai atau ajaran yang berisikan pesan moral dapat disampaikan pada anak-anak melalui bacaan. Dongeng adalah sarana yang sesuai untuk menyampaikan nilai tersebut karena cara penyampaiannya yang tidak memaksa anak-anak untuk menerimanya. Dengan dongeng, anak-anak juga tidak sekedar diajar atau dididik, melainkan diberi hiburan yang menyenangkan hati sehingga tidak cepat membuat mereka bosan.

Dalam dongeng Tsuru no Ongaeshi, identifikasi dari tindakan menolong yang dilakukan kakek berdasarkan rasa simpatinya yang tulus kepada yang ditolongnya dan tindakan burung bangau yang membalas budi kepada kakek merupakan identifikasi nilai yang berlaku pada masyarakat yang menjadi latar dongeng tersebut. Nilai itulah yang ingin disampaikan pembuat dongeng kepada anakanak yang menjadi objek dari dongeng tersebut. Dalam masa kanak-kanak, anak-anak membutuhkan pengajaran mengenai etika dan norma yang berlaku dalam masyarakat. Dengan mengidentifikasi tokoh dalam cerita ataupun perbuatan, sikap, dan tindakan tokoh, anak-anak dapat belajar norma yang baik dan buruk sesuai dengan norma yang berlaku pada masyarakat.

Konsep on dan ongaeshi yang dapat dianalisis dari dongeng yang berjudul Tsuru no Ongashi, lebih mendekati konsep on dan ongaeshi seperti yang dikemukakan Umesao Tadao yang lebih menekankan adanya keikhlasan dalam melakukan suatu pemberian, baik pemberian yang berupa hadiah maupun pemberian dalam bentuk bantuan atau pertolongan. Pemberian atau bantuan yang diberikan tidak boleh dengan suatu harapan untuk menerima balasan atas bantuan yang telah diberikan

(ongaeshi) karena dengan mengharapkan balasan berarti kita telah melalukan korupsi terhadap on itu sendiri. Membesar-besarkan pemberian on kepada orang lain juga sangat bertentangan dari prinsip utama on, seperti yang dikemukakan oleh Umesao Tadao.

\section{DAFTAR PUSTAKA}

Benedict, Ruth. 1979. Pedang Samurai dan Bunga Seruni, Pola-pola Kebudayaan Jepang. Jakarta: Sinar Harapan.

Bettelheim, Bruno. 1976. The Uses of Enchantment, The Meaning and Importance of Fairy Tales. New York: Alfred A. Knopf, Inc.

Bunanta, Murti. 1997. "Problematika Penulisan Cerita Rakyat untuk Anak di Indonesia: Telaah Penyajian dengan Contoh Dongeng Bertipe Cerita "Cinderella" dan "The Kind and Unkind Girls"'. Disertasi Program Studi Ilmu Susastra Program Pascasarjana UI.

Danandjaja, James. 1997. Folklor Jepang. Jakarta: Pustaka Utama Grafiti.

Durkheim, Emile. 1990. Pendidikan Moral: Suatu Studi Teori dan Aplikasi Sosiologi Pendidikan. Jakarta: Erlangga.

Gootoo Sooichiro （後籐総一郎）. Mukashi Banashi no Sekai:Sono Rekishi to Gendai. Heisei 12. Japan: Tono Monogatari Kenkyushou. 
昔話の世界：その歴史と現代、との物語研究書、日本

Harumi, Befu. 1971. Japan: An Antropological Introduction. New York: Chandler Publishing.

Kawai Hayao（河合 はやお）. 1982. Mukashi Banashi to Nihonjin no Kokoro, Iwanami Shoten. 昔話と日本人の心、1982、岩波書店

Komatsu Kazuhiko (ed.) 小松 和彦〉. 1985. Mukashi-Banashi Kenkyu no Kadai, Showa 60 Meisho Shuppan, Japan.

昔話研究の課題、昭和 60 、名著出版、日本

Lebra, Takie Sugiyama and William P. Lebra (ed.) 1975. Japanese Culture and Behavior, Selected Readings. The University Press of Hawaii.

Minami Hiroshi. 1971. Psychology of the Japanese People. University of Tokyo Press.

Seki Keigo （関敬吾）. Nihon Mukashi Banashi Taisei 12 Karya Besar Mukashi Banashi Jepang), Showa 58(1983), Kadogawa Shoten, Japan.

日本昔話大成 12 、昭和 58 、角川書店、日本

Stewig, John Warren. 1980. Children and Literature. Boston: Houghton Mifflin Company.

Sudjiman, Panuti. 1992. Memahami Cerita Rekaan. Jakarta: Pustaka Jaya.

Tsubota Jooji（坪田 譲冶）. 1987. Nihon no Mukashi Banashi, Kaiseishabunko, Japan. (Jilid 2,3 , dan 4)

日本の昔話、1987、偕成社文庫、日本

UmesaoTadao（うめさおただお）. 1982. Nihonjin no Kokoro. Japan: Asahi Sensho.

日本人の心、朝日選書、日本 